\title{
Metallomic study of mercury in fish from Amazon region - Brazil
}

\author{
P. M. Moraes ${ }^{1}$, F. A. Santos ${ }^{1}$, C. F. Padilha ${ }^{1}$, G. R. Castro ${ }^{1}$, L. F. Zara ${ }^{2}$ and P. M. Padlha ${ }^{4}$ \\ ${ }^{1}$ Institute of Biosciences, UNESP, Botucatu/são Paulo/BRAZIL, padilha@ibb.unesp.br \\ ${ }^{2}$ University Brasília, UNB, Brasília, Distrito Federal/BRAZIL, fabriciozara@gmail.com
}

\begin{abstract}
This paper presents preliminary findings for a metallomics study of mercury in the muscle of the fish from Amazonas region - Brazil, after protein separation by two-dimensional polyacrylamide gel electrophoresis (2D-PAGE) and subsequent evaluation of mercury by Thermal Decomposition and Amalgamation Coupled with Atomic Absorption (TTA-CAAS). It was found that mercury is present in 18 protein spots of "dourada" muscle (Brachyplatystoma rousseauxii) and 9 protein spots of "pacu" muscle (Myleus sp.). The protein spots in which they were determined the presence of mercury present molecular weight of 13.5 and $21.4 \mathrm{kDa}$ and isoelectric point of 3.8 and 9.2, respectively.
\end{abstract}

Key words: Mercury in fish, Metallomic study, 2D-PAGE, TTA-CAAS

\section{Introduction}

The environmental mercury contamination that occurred in Amazon from the 1980s up to the mid-1990s is once more under debate due to the environmental burden left by gold mining and its potential for human contamination. However, recent studies have demonstrated that high concentrations of mercury from non-anthropic sources are also found in abiotic and biotic compartments in various regions of Amazonia. Regardless of the source of contamination, studies aimed at elucidating the mechanisms of mercury toxicity are essential for the socioenvironmental development of this region (Pfeiffer et. al., 1993). The environmental changes resulting from the construction and operation of the Jirau Hydroelectric Power Plant in the Madeira river basin could alter the mercury dynamics in this environmental area. The average total mercury concentrations recorded in the last decade in the Madeira river basin (the region where the Jirau hydropower project is located) indicate that mercury concentrations have remained within their natural levels in Amazonian rivers. However, it is known that the transformation and remobilisation processes of previously unavailable mercury species can alter their chemical configuration, thereby making them available to the aquatic environment (Barbosa et. al., 1995). The metallomics - a recently proposed field of science brings together chemical and biochemical studies about the fractionation and characterisation of metal-binding proteins. This new field of science has contributed to the elucidation of the physiological and functional aspects of metalloproteins responsible for the transport of metal ions in live organisms (Haraguchi, 2004). Considering the above this paper presents preliminary results of metalloproteomics study of mercury in fish muscle samples of the JIRAU Hydroelectric Power Plant Madeira River Basin using two-dimensional polyacrylamide gel electrophoresis (2D-PAGE) and Thermal Decomposition and Amalgamation Coupled with Atomic Absorption (TTA-CAAS), with the primary objective, the possible identification of biomarkers protein of mercury.

\section{Materials and Methods}

The two fish species used in this metallomics study of mercury were chosen based on their trophic levels and because they are among the species most widely consumed by the local riverine population. These fish species were dourada (Brachyplatystoma rousseauxii), a predator species, and pacu (Mylossoma sp., Myleus sp.), an omnivorous species with a tendency to herbivory. A total of six specimens of each species were collected. The fish were anesthetised with a benzocaine solution (100 $\mathrm{mg} \mathrm{L}^{-1}$ ) and euthanised to remove muscle samples. A pooled sample of muscle from each of the specimens was ground in a ball mill, transferred to $15 \mathrm{~mL}$ polypropylene flasks and stored in a freezer at $-80^{\circ} \mathrm{C}$. The protein fraction samples of fish muscle was extracted by steeping in ultra-pure water and the proteins contained in the aqueous extrcts were precipitated using first a mixture of ethanol/chloroform and then ethanol/hydrochloric acid. The protein precipitate obtained in the second stage of precipitation was washed again twice with the same 
solution used for the precipitation. After these procedures, the protein precipitates was resolubilized in buffer containing urea $7 \mathrm{~mol} \mathrm{~L}^{-1}$, thiourea $2 \mathrm{~mol} \mathrm{~L}^{-1}$, CHAPS $2 \%(\mathrm{~m} / \mathrm{v})$, ampholytes $0.5 \% \quad(\mathrm{v} / \mathrm{v}), \mathrm{pH} 3-10$, and bromophenol blue $0.002 \%$, as well as $2.8 \mathrm{mg}$ of DTT. This mixture was used in the protein separations by 2D-PAGE. The protein spots obtained were cut out from the gel, lyophilized and analyzed by TTA-CAAS for mercury determination.

\section{Results and Discussion}

The 2D-PAGE electrophoresis experiments on samples of dourada and pacu muscle tissue were performed with four repetitions. Figure 1 shows representative gels obtained from the muscle samples of dourada and pacu, with the protein spots which identified the presence of mercury with highlighted circle. The correlation analysis of the gels demonstrated that $68 \%$ and $70 \%$ of the protein spots were present in the four gels of the dourada and pacu muscle tissue samples, respectively. In addition, the average number of spots found in the gels $-168 \pm 15$ in dourada and $98 \pm 8$ in pacu - presented a relative standard deviation of less than $10 \%$, which is considered very good for protein fractionation by 2D-PAGE (Lima et al., 2010; Santos et al., 2011).

As shown in Figure 1, the mapping of mercury by TTA-CISA indicated the presence of this element in 18 protein spots of "dourada" muscle and 9 protein spots of "pacu" muscle. The protein spots in which they were determined the presence of mercury present molecular weight of 13.5 and $21.4 \mathrm{kDa}$ and isoelectric point of 3.8 and 9.2 , respectively.

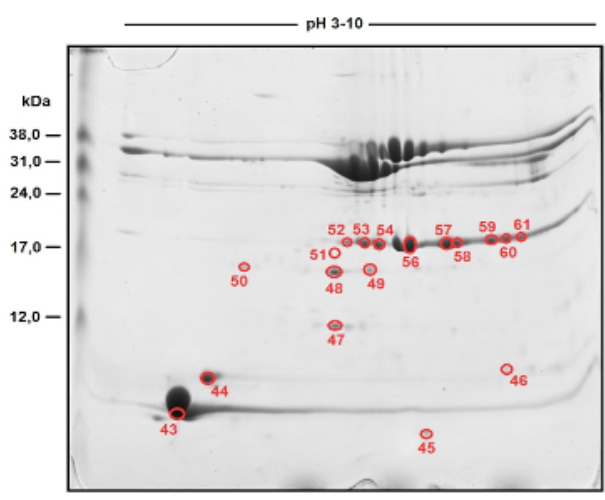

(a)

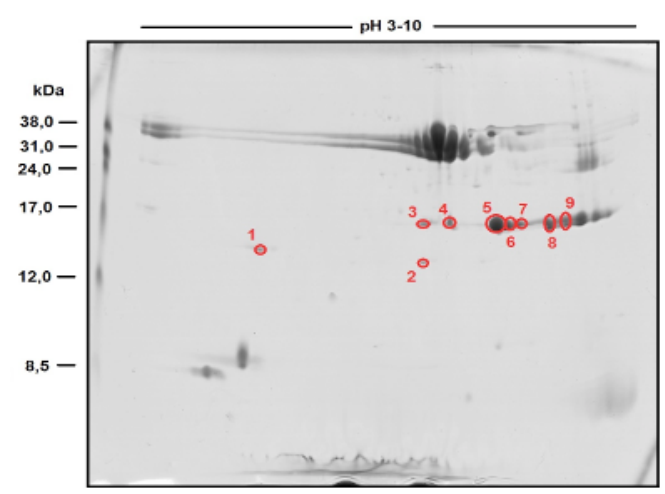

(b)

Fig. 1. Polyacrylamide gels of muscle samples of dourada (a) and pacu (b) showing the protein spots which were detected mercury by TTA-CAAS highlighted with a circle.

\section{Conclusion}

The use of 2D PAGE in the initial stage in this metallomic study of mercury in samples of muscle of dourada and pacu was efficient in the extraction of proteins and the preservation of metal-protein structure, which enable the identification of mercury in 27 protein spots by TTA-CAAS. Furthermore, the results obtained from the evaluation of mercury by TTA-CAAS indicated the presence of this element in protein spots with molecular weight less than $10 \mathrm{kDa}$ which can be metallothioneins, proteins that have functional groups with sulphur atoms that posses soft base characteristics, thus, they bind preferentially to metals with soft acid characteristics, as is the case of mercury.

\section{Acknowledgements}

The authors thank the financial supports providing from FAPESP (Process: 2009/54856-8 and 2010/51332-5).

\section{References}

Pfeiffer W. C., Lacerda L. D., Salomons W., Malm O.
Environment fate of mercury from gold mining in the Brazilian Amazon. Environ. Rev. 1:26-37, 1993.

Barbosa A. C., Boischio A. A., East G. A., Ferrari I., Gonçalves A., Silva P. R. M., Cruz T. M. E. Mercury contamination in the Brazilian Amazon. Environmental and occupational aspects. Water, Air and Soil Pollution 80(1):109-121, 1995.

Haraguchi, H. (2004). Metallomics as integrated biometal science. Journal of Analytical Atomic Spectrometry, 19, 5-14.

Lima P. M., Neves R. C. F., Santos F. A., Pérez C. A., Silva M. A. O., Arruda M. A. Z., Castro G. R., Padilha P. M.(2010). Analytical approach to the metallomic of Nile tilapia (Oreochromis niloticus) liver tissue by SR-XRF and FAAS after 2D-PAGE separation: Preliminary results. Talanta, 82,1052-1056.

Santos F. A., Lima P. M., Neves R. C. F., Moraes P. M., Pérez C. A., Silva M. A. O., Arruda M. A. Z., Castro G. R., Padilha P. M. (2011). Metallomic study of plasma samples from Nile tilapia using SR-XRF and GFAAS after separation by 2D PAGE: Initial results. Microchimica Acta, 173(1-2), 43-49. 